\title{
The Effect of Epigallocatechin-3-Gallate on Transcriptional Regulation of Migration and Inflammation Related Genes in Benign Prostate Hyperplasia Cells
}

\section{Epigallokateşin-3-gallat'ın Benign Prostat Hiperplazi Hücrelerinde Migrasyon ve Enflamasyon ile İlişkili Genlerin Transkripsiyonel Regülasyonuna Etkisi}

\author{
Burcu Erbaykent Tepedelen ${ }^{*}$
}

Gönderim Tarihi / Received: 26.11.2020

Kabul Tarihi / Accepted: 23.02.2021

DOI: $10.34087 /$ cbusbed. 831854

\section{Öz}

Giriş ve Amaç: Bu çalışmada epigallokateşin-3-gallat'ın (EGCG) benign prostat hiperplazisi hücrelerinde migrasyon ve inflamasyon ile ilişkili genlerin transkripsiyonel regülasyonundaki rolünün araştırılması amaçlanmıştır.

Gereç ve Yöntemler: EGCG uygulamasının migrasyon ile ilişkili FAK, PXN, RhoA, Rac1, Cdc42, PAK1, ROCK1,

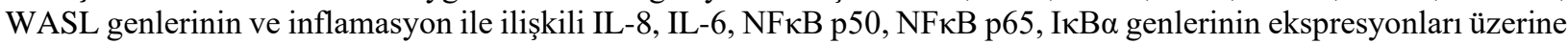
etkisi kantitatif gerçek zamanl1-polimeraz zincir reaksiyonu (qRT-PCR) kullanılarak tespit edildi.

Bulgular: EGCG uygulamasının araştırılan genlerin mRNA seviyelerinde 2 kattan fazla anlamlı bir değişikliğe yol açmadığı belirlendi. Protein fosforilasyonlarını ve seviyelerini etkili bir şekilde baskılayan EGCG'nin, migrasyon ve inflamasyon ile ilişkili genlerin transkripsiyonel regülasyonunda rol oynamadığı belirlenmiştir. Elde edilen sonuçlar, EGCG'nin büyük olasılıkla mRNA seviyelerini etkilemeden protein fonksiyonunu değiştirerek FAK ve NFאB sinyal yolaklarınının aktivitesini azalttı̆̆ını göstermektedir.

Sonuç: EGCG'nin alt idrar yolu semptomları ve BPH gibi premalign lezyonların tedavisinde faydalı olabileceği ve etki mekanizmasının baskın olarak post-translasyonel seviyede gerçekleştiği düşünülmektedir.

Anahtar kelimeler: Benign prostat hiperplazisi (BPH), EGCG, Enflamasyon, FAK, Migrasyon, NFkB.

\section{Abstract}

Objective: This study was aimed to evaluate the role of epigallocatechin-3-gallate (EGCG) in the transcriptional regulation of genes associated with migration and inflammation in benign prostate hyperplasia (BPH-1) cells.

Materials and Methods: Effect of EGCG treatment on expressions of FAK, PXN, RhoA, Rac1, Cdc42, PAK1,

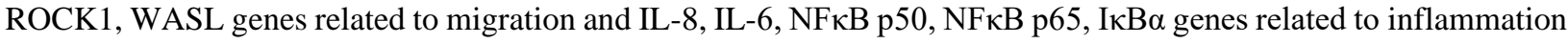
were determined by quantitative real time-polymerase chain reaction (qRT-PCR).

Results: It was determined that EGCG treatment did not significantly change the expressions of investigated genes over 2 fold in terms of mRNA levels. EGCG, which effectively suppresses protein phosphorylations and levels, does not play a role in transcriptional regulation of migration and inflammation-related genes. These results show that EGCG probably reduces the activity of FAK and NFKB signaling pathways by altering the protein function without affecting mRNA levels.

Conclusion: It is thought that EGCG may be useful in the treatment of premalignant lesions such as LUTS (lower urinary tract symptoms) and $\mathrm{BPH}$, and its mechanism of action can be predominantly realized at post-translational level.

Keywords: Benign prostatic hyperplasia (BPH), EGCG, FAK, Inflammation, Migration, NFкB. 


\section{Introduction}

Benign prostatic hyperplasia (BPH), which is a complex syndrome, starts as a simple micronodular hyperplasia with bladder outlet obstruction and subsequent macroscopic nodular enlargement that usually results in lower urinary tract symptoms (LUTS) [1-2]. BPH causes important clinical symptoms associated with prostate enlargement and chronic inflammation, and has been the most common urological disease in men for the past 50 years [3-4]. Besides the pathological changes leading to the phenotype of BPH, the specific mechanisms regulating growth and the etiology of the disease are not fully known [1-2]. However, many factors such as hormonal (androgens, estrogens, adrenergic receptors) changes, nutritional habits, environmental and inflammatory mediators are suggested to play a role in the pathogenesis and progression of $\mathrm{BPH}[2,5-6]$. In the last few years, it has been revealed that chronic inflammation and oxidative stress are the major factors that lead to the development of BPH [7].

The tissue remodeling process that occurs due to interactions in the pathway of growth factors has been found to cause prostate enlargement in men with aging [8]. Testicular androgens are required in the development of BPH and BPH tissue has higher dihydrotestosterone activity than normal prostate gland tissue [9]. Chronic inflammation contributes to the development of BPH by generating tissue damage, activating macrophages and lymphocytes, activating cytokine release and increasing the concentration of growth factors. Especially upregulation of pro-inflammatory cytokines has been widely reported in the prostate tissues of patients with $\mathrm{BPH}[4,7,10]$. IL-8, which is one of these proinflammatory cytokines produced by the prostate microenvironment, is considered to be the key link between chronic inflammation and cell proliferation, and IL-8 is thought to be a reliable marker of $\mathrm{BPH}[3,11]$. Oxidative stress is also thought to be one of the mechanisms that trigger the events, which plays a role in the development and progression of prostate hyperplasia [12]. Local hypoxia plays a role in the pathophysiology of BPH through neo-vascularization and the release of growth factors (ie, VEGF, FGF-7, TGF- $\beta$ and FGF-2) after ROS formation [13]. Finally, it was shown that focal adhesion pathway (FAK), FoxO signaling pathway and autophagy pathway can be very important for the progression of BPH in a study where key genes and pathways in BPH pathogenesis were determined via Gene Expression Omnibus (GEO) database analysis [1] Smooth muscle contraction, which is critical for $\mathrm{BPH}$ syndromes like LUTS, requires the cytoskeleton to be attached to the membranes and the membranes to the ECM. These connections firstly require activation of the focal adhesion kinase (FAK) by phosphorylation and subsequent induction of proteins such as PXN, Rho family (Rho, Rac1 and Cdc42), PAK and ROCK1 that play an important role in cell growth and migration and also cell survival pathways such as MAPK and NFKB via FAK $[1,14]$. Pharmacological treatments used for BPH, such as $\alpha$-blockers and Type I/II $5 \alpha$-reductase inhibitors, do not cause long-term regression and have side effects such as orthostatic hypotension, diarrhea, headache, nasal congestion and sexual dysfunction [2, 15]. However, it has been reported that many natural and synthetic polyphenol compounds, containing catechin group as their main characteristics, potentially show an anti-androgen effect by inhibiting $5 \alpha$-reductase activity [16-17]. Therefore, there is an increasing tendency towards phytotherapy in the treatment of $\mathrm{BPH}$ in recent years $[2,5]$.

Green tea is one of the most popular beverages commonly consumed and green tea consumption has been shown to have beneficial effects on many human diseases such as obesity, metabolic syndrome, neurodegenerative disorders, inflammatory diseases and cancer [18-19]. Catechins play a role as active polyphenols of green tea and Epigallocatechin-3-gallate (EGCG) constitute of $50-80 \%$ of total tea catechins [19]. EGCG is the most active catechin that play role on biological processes and in vitro, in vivo and clinical studies implicated the multiple anti-cancer effects such as anti-proliferative, anti-inflammatory, anti-oxidant, pro-apoptotic, anti-angiogenic and anti-invasive functions. Many of these studies have been shown that EGCG affects many signaling pathways related to tumor formation such as MAPK, PI3K-AKT, NFкB and EGFR as well as ubiquitin / proteasome degradation pathways through direct interaction with specific protein targets [20-21]. EGCG binds to several proteins such as Pin, 67LR, TGFR-II, Bcl-2, MMP-2, MMP-9, Vimentin, IGF-1R, DNMT1, DNMT3B, HDAC1, HSP90, GRP78, ZAP70, TRAF-6 and the interaction process is highly dependent on the folding state and the conformational properties of the target protein [18]. For example, the $\mathrm{BH} 3$ pocket of $\mathrm{Bcl}-2$ family proteins is considered one of the binding sites of tea polyphenols [22]. EGCG has been determined to block the activation of FAK, ERK, JNK, p38 and PI3K proteins through inhibiting phosphorylation of these molecules in many different cancer cells as well as to direct interaction [18-22]. In a study where the effectiveness of green tea catechins was clinically evaluated in HG-PIN patients, it was concluded that catechins are safe and very effective in the treatment of premalignant lesions, do not show any side effects and may help in the treatment of benign prostatic hyperplasia symptoms by reducing lower urinary symptoms [23]. In addition, EGCG has been found to reduce prostate growth and hyperplasia by suppressing oxidative damage and leading to a decrease in inflammatory markers such as IL-I $\beta$, IL-6 and TNF- $\alpha$ [24]. Furthermore, it was shown that EGCG reduced the expansion of prostatic epithelial cells and inhibited the increase in prostatic acid phosphatase and prostate relative weight levels in BPH rats at doses of 50 and $100 \mathrm{mg} / \mathrm{kg} /$ day. However, the precise pharmacological mechanisms of EGCG in BPH regression still remain uncertain [2].

Contrary to these studies, which are generally investigate the role of EGCG in post-translational regulation, there are very few publications examining the effect at the transcriptional level. In this context, this study was aimed 
to evaluate the role of EGCG in the transcriptional regulation of genes associated with migration and inflammation in BPH-1 cells. For this purpose, messenger ribonucleic acid (mRNA) levels of FAK, PXN, RhoA, Rac1, Cdc42, PAK1, ROCK1, WASL genes related to migration and IL-8, IL-6, NFאB p50, $\mathrm{NF} \kappa \mathrm{B} p 65, \mathrm{I} \kappa \mathrm{B} \alpha$ genes related to inflammation were determined by qRT-PCR in BPH-1 cells treated with certain doses of EGCG. None of the genes investigated showed up or down regulation over 2-fold in the presence of increasing doses of EGCG. Consequently, it is thought that the effect of EGCG is likely to be accomplished by altering the protein function without affecting mRNA levels.

\section{Materyal ve Metot \\ 2.1. Cell Culture}

Human benign prostate hyperplasia cell line BPH-1 was purchased from German Collection of Microorganisms and Cell cultures (Leibniz Institute DSMZ, Germany). BPH-1 cells were propagated in RPMI 1640 (Invitrogen, UK) medium supplemented with $10 \%$ FBS (Fetal bovine Serum) (Invitrogen, UK), 1\% L-glutamine (Invitrogen, $\mathrm{UK}$ ), and $1 \%$ penicillin-streptomycin (Invitrogen, UK) in a humidified incubator at $37{ }^{\circ} \mathrm{C}$ and $5 \% \mathrm{CO} 2$. Cells were removed from culture plates with trypsin-EDTA solution $(0.25 \%$, Invitrogen, UK) and subcultured to sixwell plates for further experiments.

\subsection{Cell Treatment}

According to our previous study [14], BPH-1 cells treated with $10,25,50,75$ and $100 \mu \mathrm{M}$ EGCG for $48 \mathrm{~h}$ before gene expression analysis. A stock solution of EGCG (Sigma, UK) was prepared at a concentration of 1 $\mathrm{M}$ in $\mathrm{ddH} 2 \mathrm{O}$ and stored at $+4{ }^{\circ} \mathrm{C}$ until the analysis. Control cells were incubated under same conditions without EGCG.

\subsection{Total RNA Isolation}

Total RNA was isolated from cultured BPH-1 cells, with or without EGCG, by using the Aurum Total RNA Kit (BioRad, USA) according to the manufacturer's protocols. Total RNA yields were calculated by absorbance readings at 260/280 nm. Following, complementary DNA (cDNA) synthesis was performed with iScript cDNA Synthesis Kit (BioRad, USA) as recommended by the manufacturer. Using the unique blend of oligo (dT) and random hexamer primers, $1 \mu \mathrm{g}$ of total RNA was reverse transcribed to make cDNA.

2.4.Quantitative Real Time Polymerase Chain Reaction ( $q R T-P C R)$

To examine the gene expression levels; qRT-PCR was performed using a SYBR Green PCR kit (BioRad, USA) and the BioRad CFX Connect RT-PCR instrument in 96Well Optical Reaction Plates (BioRad, USA). The following program can be employed:
Table 1. Cycling conditions for RT-PCR

\begin{tabular}{|c|c|}
\hline Stage 1 (Activation) & $95^{\circ} \mathrm{C}$ for $3 \mathrm{~min}$ \\
Stage 2 (40 repeats) & \\
Denaturating & $95^{\circ} \mathrm{C}$ for $10 \mathrm{~s}$ \\
Elongation & $58^{\circ} \mathrm{C}$ for $30 \mathrm{~s}$ \\
\hline
\end{tabular}

All of the primers were designed using Primer 3 Software. The final reaction volume of $20 \mu \mathrm{L}$ consists of $10 \mu \mathrm{L}$ of SYBR Green PCR Master Mix (BioRad, USA), 10 pmol of each primer and $2 \mu \mathrm{L}$ of cDNA. Each gene should be analyzed in triplicate with three biological repeats. The expression values of these genes were proportioned to housekeeping genes (TBP; Tata Binding Protein and GAPDH; Glyceraldehyde-3-Phosphate Dehydrogenase) to calculate the relative expression ratios. Data analysis was carried using the $\Delta \Delta^{\mathrm{CT}}$ method and quantitated by "CFX Manager 3.1 Software".

\subsection{Statistics}

Data are presented as means \pm standard deviation (SD). The statistical significance of differences between control and treatment groups was assessed by two-tailed equal variance the Student's t-test or two-way ANOVA followed by Bonferroni's post hoc test using Prism (V5, GraphPad Software) and Origin Pro (V8, OriginLab Corp) softwares, respectively. Values of $\mathrm{p}<0.05$ were considered significant.

\section{Results and Discussions}

\subsection{Results}

It was investigated that the role of EGCG in transcriptional regulation of migration and inflammation related genes in accordance with the previous results, in which we determined that EGCG reduced the phosphorylation and levels of proteins associated with the FAK signaling pathway in BPH-1 cells [14]. For this purpose, BPH-1 cells treated with EGCG for 48 hours at concentrations of 10-25-50-75 and $100 \mu \mathrm{M}$. Transcriptional regulation of genes related to migration and inflammation was detected by qRT-PCR after RNA isolations and cDNA synthesis. Relative quantification method was used for data analysis. GADPH and TBP were used as internal normalization factor and EGCG untreated BPH-1 cells were determined as external normalization factor. The fold changes determined for the mRNA levels of EGCG treated BPH-1 cells represented as graphics.

To evaluate the migratory potential of BPH-1 cells treated with EGCG in increasing concentrations, the mRNA levels of FAK signaling pathway genes including FAK, PXN, RhoA, Rac1, Cdc42, PAK1, ROCK1 and WASL was investigated. 
As shown in Figure 1, it was observed that there were no significant changes over 2 fold in the transcriptional level of the investigated genes. However, only the level of PXN gene was decreased in a dose dependent manner. While a 1.5 fold increase at $25 \mu \mathrm{M}$ concentration was observed, it was decreased to 0.64 fold at $100 \mu \mathrm{M}$ concentration and therefore totally 2.4 fold decrease was detected for PXN gene mRNA level (Figure 1a). This reduction is consistent with the decrease in PXN protein level shown in our previous study [14]. The increases observed in the Cdc42, Rac1, ROCK1 and WASL mRNA levels at $100 \mu \mathrm{M}$ EGCG concentration were not taken into consideration because of their low significance values.
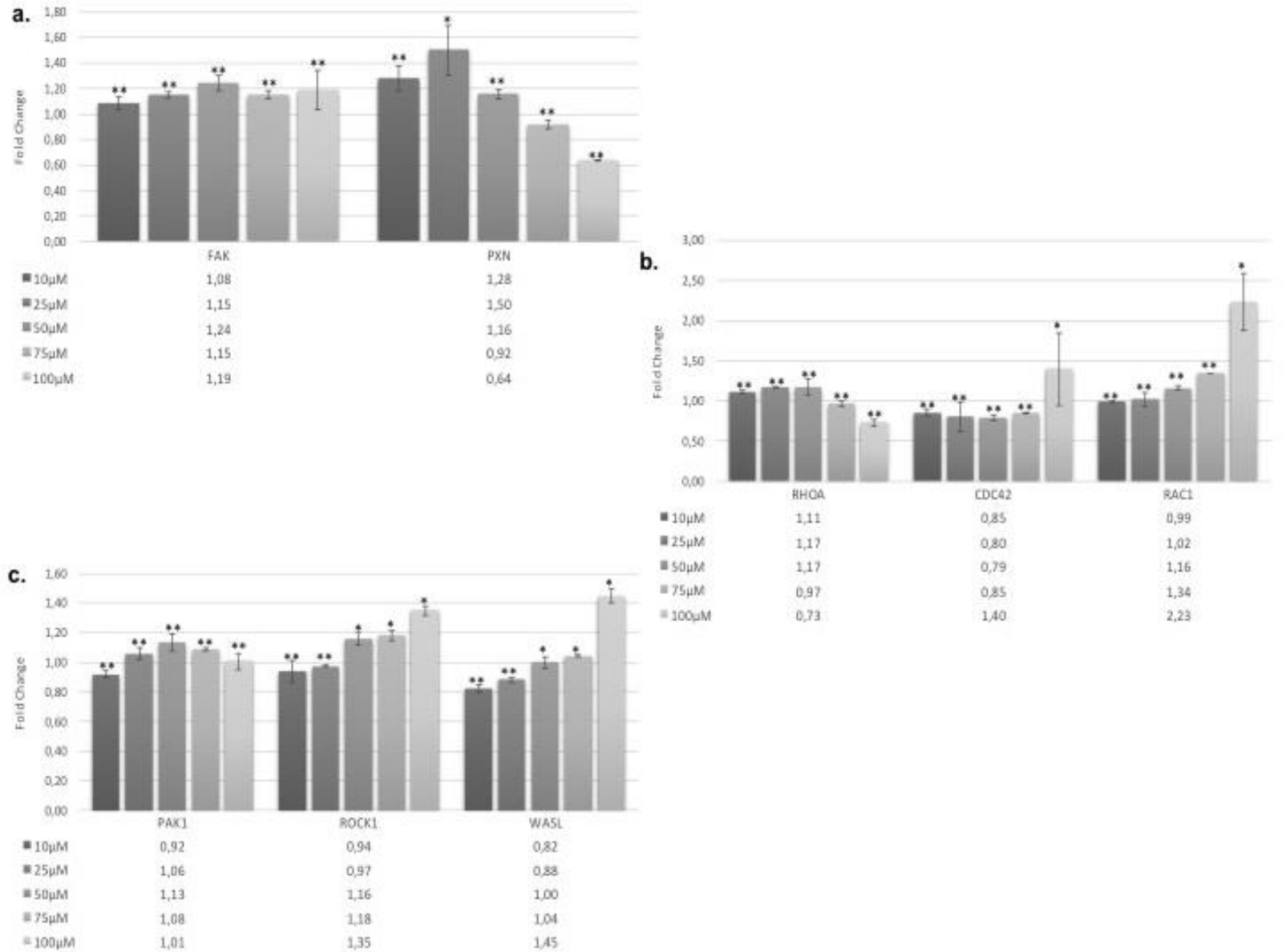

Figure 1. Effects of EGCG on mRNA levels of migration related genes. BPH-1 cells were treated with 10, 25, 50, 75 and 100 $\mu \mathrm{M}$ EGCG for 48h, then the expression level of target genes was determined by qRT-PCR. Y axis showed the fold increase or decrease. X axis showed the target genes as (a). FAK and PXN, (b). RhoA, Cdc42 and Rac1, (c). PAK1, ROCK1 and WASL. Significance was determined with paired Student's t test via GraphPad software, $* \mathrm{p} \leq 0.05 ; * * \mathrm{p} \leq 0.005$. (Abbreviations: FAK, Focal adhesion kinase; PXN, Paxillin; RhoA, Ras homolog family member A; Rac1, Ras related C3 botulınum toxın substrate 1; Cdc42, Cell division cycle 42; PAK1, p21 protein (cdc42-rac) activated kinase 1; ROCK1, Rho associated coiled-coil containing protein kinase 1; WASL, Wiskott-aldrich syndrome-like)

To determine whether EGCG effects the transcriptional regulation of inflammation related genes includes IL-8,

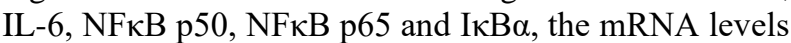
of these genes were analyzed by qRT-PCR. As shown in Figure 2, no more than 2-fold change was observed in the transcriptional level of the studied genes similarly. While there was no significant change in the level of IL-8, IL-

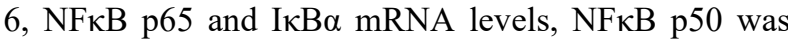
decreased in a dose dependent manner (Fig 2b). For NFкB p50 gene, a 1.26 fold increase was observed at a concentration of $10 \mu \mathrm{M}$, and this value decreased to 0.61 fold at a concentration of $100 \mu \mathrm{M}$, therefore, totally 2.1 fold reduction was determined. However, although the level of NFKB p50 mRNA was reduced in the presence of EGCG, this alteration was not affected the mRNA levels of IL-8 and IL-6 cytokines that were transcriptionally regulated by $\mathrm{NF \kappa B}$. Additionally, the fact that these cytokines are slightly down regulated compared to control is promising for treatment with natural compounds such as EGCG. Eventually, EGCG treatment did not change expressions of migration and inflammation related genes significantly in terms of mRNA levels while effectively decreased the protein levels associated with the FAK signaling, especially FAK and PXN. 

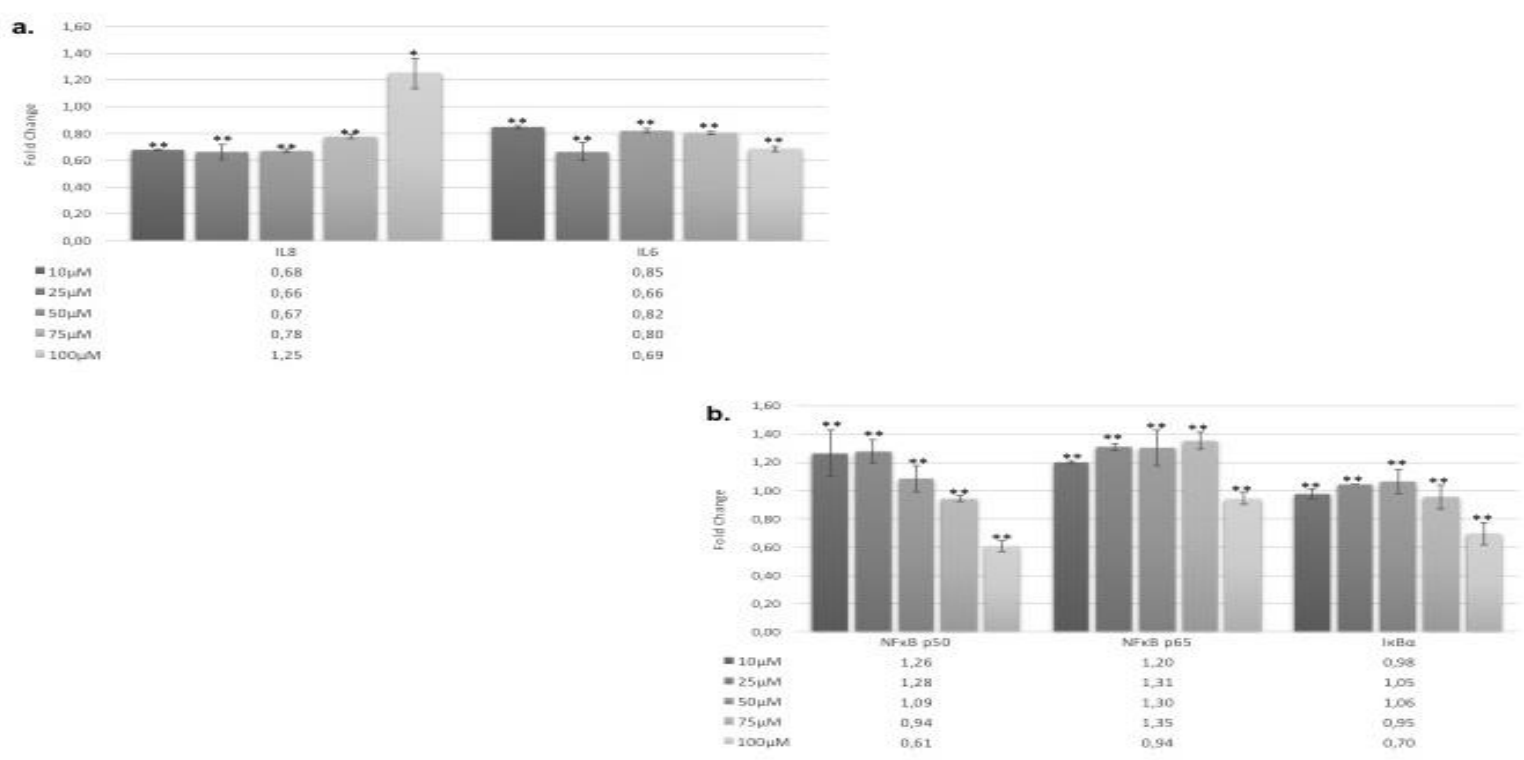

Figure 2. Effects of EGCG on mRNA levels of inflammation related genes. BPH-1 cells were treated with 10, 25, 50, 75 and $100 \mu \mathrm{M}$ EGCG for $48 \mathrm{~h}$, then the expression level of target genes was determined by qRT-PCR. Y axis showed the fold increase or decrease. X axis showed the target

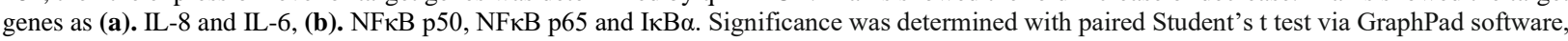

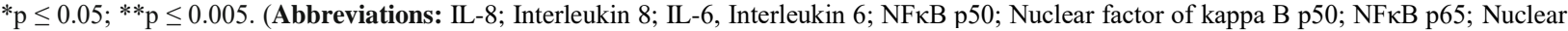
factor of kappa B p65; I $\mathrm{B} \alpha$, nuclear factor of kappa light polypeptide gene enhancer in B-cells inhibitor alpha)

\subsection{Discussions}

Some recent studies have shown that EGCG suppresses migration and adhesion of many cell types and can prevent the development of proliferative diseases [2526]. It has also been reported that EGCG suppresses the induction of $\mathrm{BPH}$ by reducing the release of proinflammatory cytokines and oxidative damage [24]. Many of these in vitro and in vivo studies show that EGCG plays a role in post-translational regulation through affecting phosphorylations, translocations, degredations, and binding activities of proteins [27]. However, it has been found that EGCG acts through interaction with specific targets and binds directly to intracellular molecules such as Pin1, membrane receptors such as TGFR-II, and secreted enzymes such as metalloproteinases (MMPs) which regulate NFKB signal, epithelial mesenchymal transition (EMT) and cellular invasion as well as 67LR, which is defined as a high affinity EGCG receptor [18]. EGCG also has a high affinity for G3BP1 (Ras-GTPase-activating protein SH3 domain-binding protein 1) and prevents Ras activation by interfering with the interaction between G3BP1 and RasGAP [28]. Conversely, the number of studies evaluating the effect of EGCG on post-transcriptional regulation remains quite limited.

FAK is a non-receptor protein tyrosine kinase localized with integrins in the focal adhesion sites and is highly expressed in the proliferative compartment of the normal prostate epithelium. FAK, a critical mediator for signaling between cells and ECM, is strongly associated with increased migratory and invasive potential of cells through Tyr397 phosphorylation in response to many stimuli such as integrin interaction and growth factors
[21]. FAK/Src signals that are formed after pFAK binding to Src, stimulate cell survival by activating the Rho family such as RhoA, Rac1 and Cdc42, as well as phosphorylation of PI3-K [29]. The RhoA pathway also plays a critical role in cell survival and drug resistance as well as it induces actin reorganization and provides cellular extensions for the migration of cells [30]. Studies show that EGCG plays an important role in signal transduction by inhibiting tyrosine phosphorylation of proteins, including FAK. EGCG inhibits receptor tyrosine kinase activity and tumor development by suppressing EGF, PDGF or FGF receptor-mediated extracellular signals [27]. It was reported that EGCG showed anti-EMT effect by leading to decreased activation of Src, FAK, and RhoA as well as inhibition of migration and invasion in oral squamous cell carcinoma cells. In these study, it was found that EGCG blocks FAK and Src activation via decreasing their phosphorylation while it does not change the level of total FAK and Src proteins [29]. In addition, it has been shown that the phosphorylation and thus activities of FAK-PI3K-ERK proteins in breast cancer cells are reduced by EGCG [21]. Furthermore, EGCG has been found to effectively inhibit both FAK and IGF-1R phosphorylations, suppressing cell adhesion and proliferation in pancreatic cancer cells. In this study, EGCG at $100 \mu \mathrm{M}$ completely inhibited the phosphorylation of FAK, while the expression of the total FAK did not change [31].

As a result of the analysis by using cDNA microarray containing 250 kinase and phosphatase genes in EGCG treated LNCaP prostate cancer cells, the genes suppressed by EGCG were mostly found to belong to the G-protein signaling network and the protein kinase C-a 
(PKC-a) form was selectively suppressed. However, it has been determined that EGCG has no effect on the phosphatidylinositol kinase family, does not cause significant changes in the expression of nuclear kinases such as casein kinase family, FAK and LIMK are not primary targets of EGCG and have little effect on some cyclin-dependent protein kinase expression. Thus, it has been concluded that post-translational control of kinase and phosphatase proteins is probably a more important level of regulation than transcription by EGCG [32]. In addition, gene expression changes have been studied with Atlas Human Cancer cDNA Expression Array in human lung cancer cell line PC-9 cells, with Macrogen 384cDNA chip in cervical cancer cells, with Macrogen 384cDNA chip in human vascular endothelial cells and they have been reported that up or down regulated genes over 2-fold with EGCG are mostly related to cell proliferation, cell cycle and apoptosis [33-35]. It was also reported by microarray analysis that the genes associated with nuclear and cytoplasmic transport, transformation, redox signaling, and hypoxia and PAH responses were also modulated by EGCG in breast cancer cells [36]. In contrast, only a few studies have obtained data indicating that EGCG decreases the level of FAK mRNA [20-21]. In accordance with most of the studies, it was observed in our results that EGCG administration did not change the mRNA levels of genes associated with the FAK signaling pathway in BPH-1 cells. In our previous study, where we investigated the anti-proliferative effect of EGCG in BPH-1 cells, it was found that EGCG did not change the total FAK protein level while decreasing the FAK phosphorylation in a dose-dependent manner and accordingly the levels of PXN, RhoA, Cdc42 and PAK1 [14]. Therefore in this study, we aimed to investigate the potential role of EGCG in transcriptional regulation and we determined that FAK, PXN, RhoA, Cdc42, Rac1, PAK1, ROCK1 and WASL mRNA levels did not change more than 2 times compared to control. Consequently, we thought that EGCG, which does not cause any change in mRNA levels, might block FAK signaling pathway at translation level especially by inhibiting FAK phosphorylation, disrupting ECM-integrin or FAK-PXN interactions or binding directly to specific protein targets. Protein tyrosine kinases such as Src and FAK play an important role in the activation of MAPK and NFKB as well as the expression of cell adhesion molecules in response to both TNF $\alpha$ and IL-1 $\beta$. Additionally, it is thought that especially FAK may also play an important role in the inflammatory cytokine signaling. FAK activity is critical for TNF $\alpha$ mediated IL- 6 and IL-8 expression by its association with RIPK1 (receptor-interacting serine/threonine protein kinase 1) and TRAF2 (TNF receptor-related factor 2) [37]. The IL-8 gene promoter contains an NF $\mathrm{NB}$ binding site required for activation in all cell types, indicating the importance of NFאB in IL-8 transcription. However, the IL-8 promoter also contains binding sites for AP-1 (activating protein-1) and C/EBP (CAAT/enhancer-binding protein) proteins. Independently from the NFKB binding site, these regions are not essential for induction but are required for maximum gene expression [38]. EGCG has been shown to inhibit NFKB activation in normal human epidermal keratinocytes or in head and neck cancer and breast cancer cells. In these studies, it has been determined that EGCG increases $\mathrm{I} \kappa \mathrm{B} \alpha$ protein levels and inhibits NF $\kappa \mathrm{B}$ nuclear translocation in a dose and time dependent manner [19, 39]. In this context, since the IL-8 is a reliable marker of $\mathrm{BPH}$ and FAK plays a role in the activation of $\mathrm{NF \kappa B}$, which play role in many cellular processes such as cell survival, proliferation, apoptosis, inflammation and immune response [11, 37, 40], this study also examined the mRNA levels of the genes associated with inflammation. Similarly with the FAK signaling pathway-related genes, EGCG treatment in BPH-1 cells did not lead to more than 2-fold change in

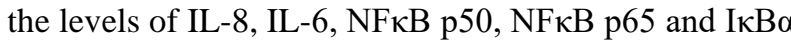
mRNA. Thus, in accordance with other studies, it was concluded that EGCG might function in posttranslational regulation by preventing IKK catalyzed I $\kappa \mathrm{B} \alpha$ phosphorylation and subsequent proteasome dependent $\mathrm{I} \kappa \mathrm{B} \alpha$ degredation and $\mathrm{NF} \kappa \mathrm{B}$ nuclear translocation while it did not act at the transcriptional level.

\section{Conclusion}

The interest in nutraceutical science has recently increased due to the effectiveness, low cost and high reliability of natural compounds and medicinal plants are often used in the treatment of prostate diseases such as benign hyperplasia, prostatis and chronic pelvic pain syndrome [24, 41]. This study is the first to evaluate whether EGCG, a green tea catechin, has an effect on transcriptional regulation in BPH-1 cells. It was shown that EGCG can inhibit BPH-1 cell proliferation through the disruption of cytoskeletal organization and ECM interactions through focal adhesions in our previos study. Additionally, it was determined that EGCG, which effectively suppresses protein phosphorylations and levels, does not play a role in transcriptional regulation of migration and inflammation-related genes such as FAK, PXN, RhoA, NFאB and IL- 8 because it does not significantly change the mRNA levels. Studies conducted to date show that there is no mutually clear relationship between transcript and protein levels. In other words, steady state mRNA levels may not correlate well with the protein composition in the cell. These results show that EGCG probably reduces the activity of FAK and NFKB signaling pathways through posttranslational regulation by preventing protein activity via blocking phosphorylation modifications, modifying protein degredation and stability, or interacting directly with target proteins. Eventually, it is thought that EGCG may be useful in the treatment of premalignant lesions such as LUTS and BPH, and its mechanism of action can be predominantly realized at post-translational level.

\section{Acknowledgements and Disclosures}

This research was supported with grants [TUBITAK 113S700] from the Turkish Scientific and Technological Research Council. 


\section{References}

1. Ke, Z.B, Cai, H, et al., Identification of key genes and pathways in benign prostatic hyperplasia, Journal of Cellular Physiology, 2019, 234(11), 19942-19950.

2.Zhou, J, Lei, Y, Chen, J, Zhou, X, Potential ameliorative effects of epigallocatechin-gallate against testosterone-induced benign prostatic hyperplasia and fibrosis in rats, International Immunopharmacology, 2018, 64, 162-169.

3.Penna, G, Fibbi, B, et al., The Vitamin D Receptor Agonist Elocalcitol Inhibits IL-8-Dependent Benign Prostatic Hyperplasia Stromal Cell Proliferation and Inflammatory Response by Targeting the RhoA/RhoKinase and NF-kB Pathways, The Prostate, 2009, 69 480-493.

4. Iglesias-Gato, D, Carsten, T, et al., Androgen-independent effects of Serenoa repens extract (Prostasan $\AA$ ) on prostatic epithelial cell proliferation and inflammation, Phytotherapy Research: PTR, 2012, 26(2), 259-264.

5.Eleazu, C, Eleazu, K, Kalu, W, Management of Benign Prostatic Hyperplasia: could dietary polyphenols be an alternative to existing therapies?, Frontiers and Pharmacology, 2017, 8(234), 1-11.

6. Briganti, A, Capitanio, U, et al., Benign prostatic hyperplasia and its etiologies, European Urology Supplements, 2009, 8, 865-71.

7.De Nunzio, C, Kramer, G, et al., The controversial relationship between benign prostatic hyperplasia and prostate cancer: the role of inflammation, European Urology, 2011, 60, 106-117.

8. Untergasser, G, Madersbacher, S, Berger, P, Benign prostatic hyperplasia: age-related tissue-remodeling, Experimental Gerontology, 2005, 40, 121-128.

9. Roberts, R.O, Jacobson, D.J, Rhodes, T, Klee, G.G, Leiber, M.M, Jacobsen, S.J, Serum sex hormones and measures of benign prostatic hyperplasia, Prostate, 2004, 61(2), 124-131.

10. Giri, D, Ittmann, M. Interleukin-8 is a paracrine inducer of fibroblas growth factor 2, a stromal and epithelial growth factor in benign prostatic hyperplasia, The American Journal of Pathology, 2001, 159, 139-147.

11. Chughtai, B, Lee, R, Te, A, Kaplan, S, Role of Inflammation in Benign Prostatic Hyperplasia, Reviews in Urology, 2011, 13, 147 150 .

12. Minciullo, P.L, Inferrera, A, Navarra, M, Calapai, G, Magno, C, Gangemi, S, Oxidative stress in benign prostatic hyperplasia: a systematic review, Urologia Internationalis, 2015, 94(3), 249-254.

13. Wang, L, Yang, J.R, Yang, L.Y, Liu, Z.T, Chronic inflammation in benign prostatic hyperplasia: implications for therapy, Medical Hypotheses, 2008, 70(5), 1021-1023.

14. Erbaykent Tepedelen, B, Soya, E, Korkmaz, M, Epigallocatechin-3 gallate reduces the proliferation of benign prostatic hyperplasia cells via regulation of focal adhesions, Life Sciences, 2017, 191, 74-81.

15. Sarbishegi, M, Khani, M, Salimi, S, Valizadeh, M, Sargolzaei Aval, $\mathrm{F}$, Antiproliferative and antioxidant effects of Withania coagulans extract on benign prostatic hyperplasia in rats, Nephro-Urology Monthly, 2016, 8(1), e33180.

16. Grant, P, Ramasamy, S. An update on plant derived anti-androgens, International Journal of Endocrinology and Metabolism, 2012, 10(2), 497-502.

17. Hiipakka, R.A, Zhang, H.Z, Dai, W, Dai, Q, Liao, S, Structureactivity relationships for inhibition of human $5 \alpha$-reductases by polyphenols, Biochemical Pharmacology, 2002, 63, 1165-1176.

18. Negri, A, Naponelli, V, Rizzi, F, Bettuzzi, S, Molecular Targets of Epigallocatechin-Gallate (EGCG): A Special Focus on Signal Transduction and Cancer, Nutrients, 2018, 10(12), 1936.

19. Singh, B.N, Shankar, S, Srivastava, R.K, Green tea catechin, epigallocatechin-3-gallate (EGCG): mechanisms, perspectives and clinical applications, Biochemical Pharmacology, 2011, 82(12), 1807-1821.

20. Luo, X, Guo, L, Zhang, L, Hu, Y, Shang, D, Ji, D, Bioinformatics analysis of microarray profiling identifies the mechanism of focal adhesion kinase signalling pathway in proliferation and apoptosis of breast cancer cells modulated by green tea polyphenol epigallocatechin 3-gallate. The Journal of Pharmacy and Pharmacology, 2018, 70(12), 1606-1618.

21. Sen, T, Dutta, A, Chatterjee, A, Epigallocatechin-3-gallate (EGCG) downregulates gelatinase-B (MMP-9) by involvement of FAK/ERK/NFkappaB and AP-1 in the human breast cancer cell line MDA-MB-231, Anti-cancer Drugs, 2010, 21(6), 632-644.

22. Khan, N, Afaq, F, Saleem, M, Ahmad, N, Mukhtar, H, Targeting multiple signaling pathways by green tea polyphenol (-)- epigallocatechin-3-gallate, Cancer Research, 2006, 66(5), 2500 2505

23. Bettuzzi, S, Brausi, M, Rizzi, F, Castagnetti, G, Peracchia, G, Corti, A, Chemoprevention of human prostate cancer by oral administration of green tea catechins in volunteers with high-grade prostate intraepithelial neoplasia: a preliminary report from a one-year proofof-principle study, Cancer Research, 2006, 66(2), 1234-1240.

24. Chen, J, Song, H, Protective potential of epigallocatechin-3-gallate against benign prostatic hyperplasia in metabolic syndrome rats, Environmental Toxicology and Pharmacology, 2016, 45, 315-320.

25. Ganguly, K.K, Sen, T, Pal, S, Biswas, J, Chatterjee, A, Studies on focal adhesion kinase in human breast cancer cell MDA-MB-231, Advances in Biological Chemistry, 2012, 2, 29-42.

26. Chan, C.M, Huang, J.H, Chiang, H.S, Wu, W.B, Lin, H.H, Hong, J.Y, Hung, C.F, Effects of (-)-epigallocatechin gallate on RPE cell migration and adhesion, Molecular Vision, 2010, 16, 586-595.

27. Sajadimajd, S, Bahramsoltani, R, et al., Advances on Natural Polyphenols as Anticancer Agents for Skin Cancer, Pharmacological Research, 2020, 151, 104584.

28. Zhang, C.H, Wang, J.X, Cai, M.L, Shao, R, Liu, H, Zhao, W.L, The roles and mechanisms of G3BP1 in tumour promotion, Journal of Drug Targeting, 2019, 27(3), 300-305.

29. Hwang, Y.S, Park, K.K, Chung, W.Y, Epigallocatechin-3 gallate inhibits cancer invasion by repressing functional invadopodia formation in oral squamous cell carcinoma, European Journal of Pharmacology, 2013, 715, 286-295.

30. Tsujimura, A, Fukuhara, S, et al., Histologic evaluation of human benign prostatic hyperplasia treated by dutasteride: a study by xenograft model with improved severe combined immunodeficient mice, Urology, 2015, 85(1), 274.e1-274.e8.

31. Vu, H.A, Beppu, Y, et al., Green tea epigallocatechin gallate exhibits anticancer effect in human pancreatic carcinoma cells via the inhibition of both focal adhesion kinase and insulin-like growth factor-I receptor, Journal of Biomedicine \& Biotechnology, 2010, 2010, 290516.

32. Wang, S.I, Mukhtar, H, Gene expression profile in human prostate LNCaP cancer cells by (2) epigallocatechin-3-gallate, Cancer Letters, 2002, 182, 43-51.

33. Okabe, S, Fujimoto, N, Sueoka, N, Suganuma, M, Fujiki, H Modulation of gene expression by (-)-epigallocatechin gallate in PC9 cells using a cDNA expression array, Biological and Pharmaceutical Bulletin, 2001, 24(8), 883-886.

34. Ahn, W.S, Huh, S.W, et al., A major constituent of green tea, EGCG, inhibits the growth of a human cervical cancer cell line, CaSki cells, through apoptosis, G (1) arrest, and regulation of gene expression, DNA Cell Biology, 2003, 22(3), 217-224.

35. Sartipp our, M.R, Heber, D, et al., cDNA microarray analysis of endothelial cells in response to green tea reveals a suppressive phenotype, International Journal of Oncology, 2004, 25(1), 193-202.

36. Guo, S, Yang, S, Taylor, C, Sonenshein, G.E, Green tea polyphenol epigallocatechin-3 gallate (EGCG) affects gene expression of breast cancer cells transformed by the carcinogen 7,12dimethylbenz[a]anthracene, The Journal of Nutrition, 2005, 135, 2978S-2986S.

37. Murphy, J.M, Jeong, K, et al., FAK and Pyk2 activity promote TNF$\alpha$ and IL-1 $\beta$-mediated pro-inflammatory gene expression and vascular inflammation, Scientific Reports, 2019, 9, 7617.

38. Hoffmann, E, Breiholz, O.D, Holtmann, H, Kracht, M, Multiple control of interleukin-8 gene expression, Journal of Leukocyte Biology, 2002, 72, 847-855.

39. Hsu, A, Bruno, R.S, et al., Dietary soy and tea mitigate chronic inflammation and prostate cancer via NFKB pathway in the Noble rat model, The Journal of Nutritional Biochemistry, 2011, 22(5), 502510.

40. Baloğlu M, Özkorkmaz E.G, Menisküs Yırtığı Hastalarının Sinoviyal Hücrelerinde Matriks Metalloprotein-2 ve NFкB Protein Ekspresyonu, Celal Bayar University-Health Science Institute Journal, 2019, 6(4), 209-214.

41. Cicero, A.F, Allkanjari, O, et al., Nutraceutical treatment and prevention of benign prostatic hyperplasia and prostate cancer, Archivio Italiano di Urologia e Andrologia, 2019, 91(3), 139-152. 
http://edergi.cbu.edu.tr/ojs/index.php/cbusbed isimli yazarın CBU-SBED başlıklı eseri bu Creative Commons Alıntı-Gayriticari4.0 Uluslararası Lisansı ile lisanslanmıştır.

(c) (7) (8) 